\title{
Obitary, Kauko Aromaa (1943-2019), Criminologist
}

\section{Tapio Lappi-Seppälä \& Natalia Ollus}

Criminologist Kauko Aromaa passed away suddenly in his sleep on 18th January 2019 in his home at the age of 75 .

Kauko Aromaa was a colorful person, who left a visible mark in Finnish criminology. He started his career in 1970 at the Institute of Criminology, a precursor for the current Institute of Criminology and Legal Policy at the University of Helsinki. His very first study "Everyday Violence in Finland" (1971) paved the way for the development of Finnish victimization surveys and indicators for the measurement of crime and crime damages, a field in which Kauko Aromaa played the leading

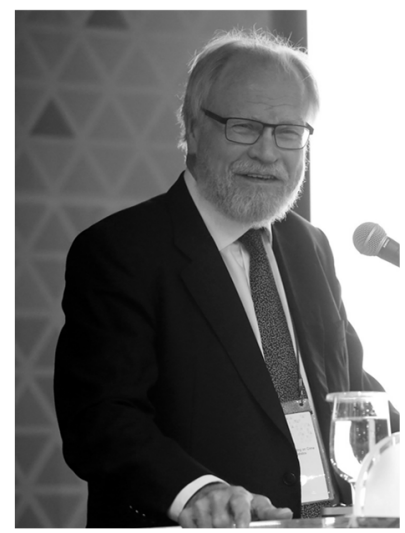
role throughout the 1980s and 1990s.

Kauko took active part in international co-operation and the advancement of crime and criminal justice statistics, both as a member of the European Sourcebook Working group and as a member of several working groups of the European Society of Criminology (ESC). Thanks to his activity Finland also became an active participant in the international victimization studies from the very first survey in 1989 onwards.

Kauko was a member of the board of the ESC in 2005-2006 and he acted as the president of the association in 2006-2007. He was also the key-organizer of the 3rd annual meeting of the European Society of Criminology, held in Helsinki 2003. In 2011 Kauko Aromaa was awarded the Freda Adler Distinguished Scholar Award by the American Society of Criminology.

Kauko was a key person in Nordic criminological meetings from the 1970s onwards. He gave a lasting input into the development of Nordic research cooperation and to the building of connections between researchers and research institutes across the Nordic countries, continuing here the work that had been instigated by his predecessors in the Institute of Criminology, Inkeri Anttila and Patrik Törnudd during the 1960s. Kauko Aromaa was a long-lasting member of the 
board of the Scandinavian Criminological Council in 1989-2002 and he acted as the president of the Council in 2001-2003.

In 2000 he was appointed as the director of the European Institute for Crime Prevention and Control, affiliated with the United Nations (HEUNI). By virtue of his vast networks, Kauko got the institute engaged in various European research projects, thus expanding HEUNI's research endeavors into new areas. This included research in 2008 into labour exploitation and human trafficking for the purpose of forced labour, making HEUNI among the first institutes in Europe to take up this topic. Upon retirement in 2011, he was appointed a professor at the University of Manchester, continuing his career in academia. He continued to participate in European research projects until his death.

As a criminologist, Kauko could be characterized as one of the last "Genuine Generalists". His expertise and interest covered a broad field of major issues of criminological interest; an increasingly rare feature, when ever more researches seem to know more and more of less and less. Aromaa published swiftly and extensively across various topics on crime, crime policy and crime prevention, both nationally and internationally. In his capacity as a researcher, he was brimming with ideas. His reactions to societal changes were quick and incisive, and he broadened the horizons for research into cross-border crime, corporate safety and human trafficking already in the 1990s. A subject he was particularly intrigued by the 1990s about was the criminality in the neighboring countries of Finland, both Russia and the Baltic countries. Kauko worked closely with Baltic colleagues and contributed with significant input into the development of victimization surveys in the region.

Kauko Aromaa did not isolate himself in the ivory tower of academic research. Instead, he took his media-responsibility seriously, always willing to comment and consult with the media. In the course of numerous TV-interviews and newspaper reports his figure became familiar for the Finnish audience as a criminologist who had the ability to place the problems in its right scale, and with a language that everyone could understand. Rational and humane criminal policy needs its defenders. Kauko was one of the key figures in the Finnish research community to take on this important, yet seldom rewarding, role.

According to Bertolt Brecht, "Finns keep silent in two languages". This, however, certainly did not apply to Kauko. Making Kauko attend a meeting, or having him give a speech or a presentation, was not difficult. According to his own words, "even a worse seminar is better than staying at home". Indeed, Kauko was a regular sight in criminological conferences and seminars. Seeing his figure pushing through the crowds always with his black "Marimekko bag" full of all 
sorts of strange stuff, joking, laughing and talking practically to everyone. During the social events around the conferences, we - more often than not - had the possibility to witness Kauko's talents as a singer, often inspired by the songs from resistance movements or Finnish tango. There was not an occasion that would have been unfit for a little song - or two - whether it would be a high-level Nordic criminalist meeting with several hundred participants, or a singing-contest with an ex-Russian general at the HEUNI international advisory board dinner.

Kauko carried the intellectual and social heritage of the radical 1960s - the protection of the weak and socially marginalized - throughout his whole life. Already as a student he was one of the founding members of the social liberal "November movement" established in Finland in 1967 against social injustices and for the improvement of prisoners' rights and the living conditions of homeless people. After his retirement, he continued to work as a board member of the Helsinki Mother and Child Home Association, supporting children and families in difficult and insecure situations and preventing domestic violence.

Those who had the opportunity to work together with Kauko, remember him as a colleague who never lost his temper and good mood, and who always had time for discussion - and always with a point. We remember him also as a man who loved books, so much that he seemed to want to literally be surrounded by them. Some of us can still picture Kauko sitting in his office surrounded by a massive fortification of stacks of books and papers so that his presence could only be confirmed by the occasional glimpse of a beard and spectacles between the piles. - But most of all, we remember Kauko as a well-read, educated, intellectually curious and friendly person, with great sense of humor. 